\section{Conclusions}

Occult bleeding from the gastro-intestinal tràct for which no cause can be found is not uncommon in cases of iron-deficiency anaemia.

A follow-up study of 68 patients in whom this diagnosis was made after initial investigation has revealed only 17 in whom some cause of bleeding became apparent (in 12 aspirin ingestion, in two bleeding piles, in one a gastric ulcer, in one a possible carcinoma of the rectum, and in one a carcinoma of the colon). The great majority of the remaining 51 patients were in good health two to 21 years after their initial investigation. Recurrence of the anaemia was frequent, occurring in over half the group, but it appeared to respond satisfactorily to oral iron.

We are grateful to the large number of general practitioners who actively co-operated with us in the follow-up study, to Mr. J. R. P. O'Brien, director of the Nuffield Department of Clinical Biochemistry, whose department performed the occult blood tests, and to Dr. Sheila Callender and other colleagues in the Nuffield Department of Clinical Medicine.

\section{REFERENCES}

Alvarez, A. S., and Summerskill, W. H. J. (1958). Lancet, 2, 920.

Avery Jones, F., and Gummer, J. W. P. (1960). Clinical Gastroenterology. Blackwell Scientific Publications, Oxford.
Badenoch, J., Evans, J. R., and Richards, W. C. D. (1957). Brit. F. Haemat., 3, 175 .

Bannerman, R. M. (1957). Brit. med. 7., 2, 1032.

Bedford, P. D., and Wollner, L. (1958). Lancet, 1, 1144.

Bel, A. (1959). Les Anémies Hypochromes de l'Adulte. Etude clinique et hématologique à propos de 410 observations. Imp. Bosc. Frères, Lyons.

Beveridge, B. R., Bannerman, R. M., Evanson, J., and Witts, L. J. In preparation.

Bock, O. A. A., Kemp, F. H., and Richards, W. C. D. (1963). Brit. F. Radiol., 36, 578.

Ebaugh, F. G., Clemens, T., Rodnan, G., and Peterson, R. E. (1958). Amer. F. Med., 25, 169.

Fry, J. (1961). Brit. med. 7., 2, 1732.

de Gruchy, G. C. (1958). Clinical Haematology in Medical Practice. Blackwell Scientific Publications, Oxford.

Heath, C. W., and Patek, A. J. (1937). Medicine (Baltimore), 16, 267

Hoag, M. S., Wallerstein, R. O., and Pollycove, M. (1961). Pediatrics, $27,199$.

Huntsman, R. G., and Liddell, J. (1961). F. clin. Path., 14, 436.

Joske, R. A., and Vaughan, B. F. (1962). Gastroenterology, 42, 7.

Kay, A. W. (1962). Brit. med. f., 1, 1709.

Mendeloff, A. I. (1953). f. Amer. med. Ass., 152, 798.

Moore, C. V. (1950). Editorial, Blood, 5, 876.

Needham, C. D., and Simpson, R. G. (1952). Quart. F. Med., 21, 123.

Retzlaff, J. A., Hagedorn, A. B., and Bartholomew, L. G. (1961). 7. Amer. med. Ass., 177, 104.

Wood, I. J., and Taft, L. I. (1958). Diffuse Lesions of the Stomach. Arnold, London.

\title{
Non-toxic Goitre in Males
}

\author{
R. MCG. HARDEN,* M.B. ; W. D. ALEXANDER,* M.D., M.R.C.P.GLASG., M.R.C.P.ED. \\ M. T. HARRISON,* M.D., M.R.C.P.
}

Brit. med. F., 1964, 1, 1419-1421

In most surveys of the incidence of non-toxic goitre it has been noted that women are predominantly affected. This is true of most forms of thyroid disease and is one of the puzzling features of disorders of this gland. There is evidence that in the west of Scotland, where goitre is seen relatively infrequently, the commonest form of non-toxic goitre is associated with iodine deficiency (Koutras et al., 1960; Wayne et al., 1964). However, some patients have inborn errors of thyroid hormone synthesis (McGirr, 1960 ; Dimitriadou et al., 1961). It has been suggested that goitrogens in the milk may be important (Kilpatrick et al., 1963). Other forms of nontoxic goitre-for example, Hashimoto's disease, drug-induced goitre, and thyroid neoplasms-are seen relatively infrequently, at least in women. We have investigated a group of males with non-toxic goitre to see whether these aetiological factors were of greater importance in this sex.

\section{Methods}

In 1961 and 196224 males with non-toxic goitre were referred to the thyroid clinic of the Western Infirmary, Glasgow, for investigation. Details of these patients are shown in Table I. The serum protein-bound iodine (P.B.I.) was measured by the method of Farrell and Richmond (1961). Standard radioiodine $\left({ }^{131} \mathrm{I}\right)$ tests including measurements of 4- and 48-hour thyroid uptake and P.B. ${ }^{131}$ I levels at 48 hours were carried out as described by Macgregor and Wayne (1958). * From the University Department of Medicine, Gardiner Institute,
Western Infirmary, Glasgow.
The thyroid clearance of iodine, plasma inorganic iodine (P.I.I.), absolute iodine uptake of the thyroid gland (A.I.U.), and renal clearance of iodine were measured using the methods described by Alexander et al. (1962). The normal ranges in our laboratory are shown in Table II. In patients taking iodides, thyroxine in the serum was measured by separation from other iodine-containing compounds on a resin column, as described by Pileggi et al. (1961). The urine was tested for monoiodotyro-

TABLE I.-Goitre in Males

\begin{tabular}{|c|c|c|c|c|}
\hline $\begin{array}{l}\text { Case } \\
\text { No. }\end{array}$ & $\begin{array}{c}\text { Age in } \\
\text { Years }\end{array}$ & $\begin{array}{c}\text { Estimated } \\
\text { Size of Goitre }\end{array}$ & $\begin{array}{l}\text { Associated } \\
\text { Diseases }\end{array}$ & Diagnosis \\
\hline $\begin{array}{l}1 \\
2 \\
3 \\
4 \\
5\end{array}$ & $\begin{array}{l}41 \\
18 \\
37 \\
45 \\
41\end{array}$ & $\begin{aligned} & 100 \mathrm{~g} . \\
& 75 \\
& 75 \\
& 75 \\
& 75,\end{aligned}$ & $\begin{array}{l}\text { "Allergy to fish" } \\
\text { Klinefelter's syndrome } \\
\text { Mental deficiency }\end{array}$ & $\left\{\begin{array}{l}\text { Iodine- } \\
\text { deficient } \\
\text { goitre }\end{array}\right.$ \\
\hline $\begin{array}{l}6 \\
7 \\
8 \\
9\end{array}$ & $\begin{array}{l}45 \\
28 \\
19 \\
42\end{array}$ & $\begin{array}{r}75, " \\
50 ", \\
100 ", \\
200, "\end{array}$ & $\begin{array}{l}\text { Bronchial asthma } \\
\text { " ” } \\
\text { Treated thyrotoxicosis }\end{array}$ & $=\underset{\text { goitre }}{\text { Drug-induced }}$ \\
\hline $\begin{array}{l}10 \\
11 \\
12 \\
13 \\
14\end{array}$ & $\begin{array}{l}63 \\
61 \\
43 \\
52 \\
67\end{array}$ & $\begin{array}{l}75, \\
50 ", \\
50 ", \\
75, " \\
75,\end{array}$ & $\begin{array}{c}\overline{-} \\
\overline{=} \\
\begin{array}{c}\text { Systemic lupus and } \\
\text { rheumatoid arthritis }\end{array}\end{array}$ & $\begin{array}{l}\text { Autoimmune } \\
\text { thyroiditis }\end{array}$ \\
\hline $\begin{array}{l}15 \\
16\end{array}$ & $\begin{array}{l}48 \\
39\end{array}$ & $\begin{array}{l}50 " \\
50 \%\end{array}$ & Klinefelter's syndrome & 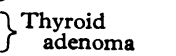 \\
\hline $\begin{array}{l}17 \\
18 \\
19 \\
20 \\
21\end{array}$ & $\begin{array}{l}57 \\
65 \\
22 \\
30 \\
76\end{array}$ & $\begin{array}{rl}50 & \Rightarrow \\
75 & ” \\
50 & " \prime \\
100 & ”\end{array}$ & $\begin{array}{l}\bar{z} \\
\bar{z}\end{array}$ & $\begin{array}{l}\text { Thyroid } \\
\text { carcinoma }\end{array}$ \\
\hline $\begin{array}{l}22 \\
23 \\
24\end{array}$ & $\begin{array}{l}42 \\
54 \\
37\end{array}$ & $\begin{array}{r}70 ", \\
100 " \text { " } \\
50\end{array}$ & $\bar{z}$ & Uncertain \\
\hline
\end{tabular}


sine and diiodotyrosine by the methods of Galton and PittRivers (1959). The precipitin test for thyroglobulin autoantibodies and the complement-fixation test were carried out by the method of Anderson et al. (1959). In seven patients thyroidectomy was performed because of a suspicion of malignancy. None of the patients was clinically thyrotoxic as judged by the " diagnostic index" (Crooks et al., 1959), and in all cases the serum P.B.I. was normal or low, except in the patients taking iodine, in whom the serum thyroxine levels were low or normal.

\section{Results}

Evidence of iodine deficiency was found in five patients (Table II). The plasma inorganic iodine levels ranged from 0.02 to $0.07 \mu \mathrm{g}$. $/ 100 \mathrm{ml}$. (normal range $0.08-0.6 \mu \mathrm{g}$.) In four patients the thyroid radioiodine clearance was raised, but in every case the absolute iodine uptake was within normal limits.

\begin{tabular}{|c|c|c|c|c|c|c|}
\hline $\begin{array}{l}\text { Case } \\
\text { No. }\end{array}$ & $\begin{array}{l}\text { Fish } \\
\text { Intake }\end{array}$ & $\begin{array}{l}\text { Thyroid } \\
\text { Clearance } \\
\text { (ml./min.) }\end{array}$ & $\begin{array}{c}\text { P.I.I. } \\
(\mu \mathrm{g} . \dot{\mathrm{m}} \\
100 \mathrm{ml} .)\end{array}$ & $\begin{array}{l}\text { A.I.U.U. } \\
(\mu \mathrm{g} . \mathrm{hr} .)\end{array}$ & $\begin{array}{c}\text { Renal } \\
\text { Clearance } \\
\text { (ml./min.) }\end{array}$ & $\begin{array}{c}\text { P.B.I. } \\
(\mu \mathrm{g} .1 \\
100 \mathrm{ml} .)\end{array}$ \\
\hline 1 & & $72 \cdot 2$ & 0.04 & 1.7 & 34.8 & $4 \cdot 5$ \\
\hline 2 & $\begin{array}{l}\text { Twice } \\
\text { yearly }\end{array}$ & $179 \cdot 7$ & 0.03 & $3 \cdot 1$ & $38 \cdot 8$ & $4 \cdot 7$ \\
\hline $\begin{array}{l}4 \\
5\end{array}$ & $\begin{array}{l}\text { Fort- } \\
\text { nightly } \\
\text { Nil }\end{array}$ & $\begin{array}{r}89 \cdot 0 \\
13.5 \\
138 \cdot 9\end{array}$ & $\begin{array}{l}0.03 \\
0.07 \\
0.02\end{array}$ & $\begin{array}{l}1.6 \\
0.6 \\
1.7\end{array}$ & $\begin{array}{l}19 \cdot 0 \\
30 \cdot 1 \\
51 \cdot 3\end{array}$ & $\begin{array}{l}4 \cdot 1 \\
4 \cdot 4 \\
2 \cdot 3\end{array}$ \\
\hline \multicolumn{2}{|c|}{ al range } & $8-40$ & $0.08-0.6$ & $0.5-6$ & $15-55$ & $3 \cdot 5-7 \cdot 5$ \\
\hline
\end{tabular}

The serum P.B.I. was normal except in one patient with severe iodine deficiency, in whom it was low (Table II). A similar picture might result from deiodinase deficiency, but neither monoiodotyrosine nor diiodotyrosine was found in the urine. Three of the five had a very low dietary intake of iodine. Two patients had eaten no fish for over 20 years ; one maintained that it induced an allergic skin rash and the other had a marked aversion to fish. One patient disliked fish and ate it only twice a year. It was impossible to obtain a diet history from one patient who was feebleminded. A fifth patient had Klinefelter's syndrome and ate fish about twice a fortnight.

Three patients were found to have iodine-induced goitre; all had taken iodine-containing preparations for asthma for several years (Table III). The thyroid clearance was abnormally high in relation to the level of the plasma inorganic iodine, resulting in the accumulation of large amounts of iodine. One patient (Case 9) had taken $30 \mathrm{mg}$. of carbimazole daily for three years, and further detailed studies are given in the appendix which confirm that this is the main basis of the goitre.

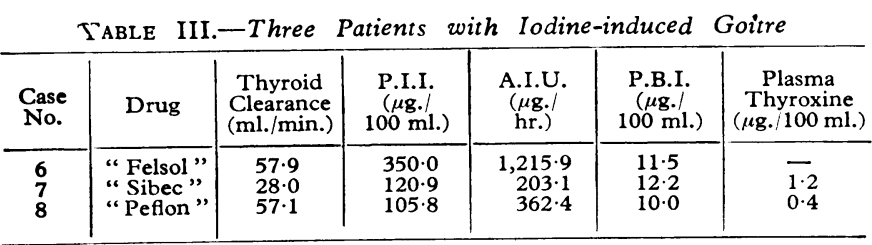

In five cases the diagnosis of autoimmune thyroiditis was made (Table IV). The association, shown here, of low or normal radioiodine uptake with a high $P . B .{ }^{131} \mathrm{I}$ at 48 hours is a usual feature of Hashimoto's disease (Buchanan et al., 1961). Three of the five patients were hypothyroid.

Seven patients had thyroid tumours. Two of these were simple adenomas-one in a patient with Klinefelter's syndrome - and five were carcinomas, three of them with metastases to local lymph nodes. Of the carcinomas four were papillary adenocarcinomas and one was anaplastic.

In three patients (Table $\mathrm{V}$ ) the cause of goitre remained in doubt. Each one showed features not present in any other patient in the series. One developed an acute and painful swelling of his thyroid gland which subsided over the next month. When seen two months later he was euthyroid, with a small nodular goitre. All tests of thyroid function were then normal. It is likely that this patient had either subacute thyroiditis (de Quervain's) or haemorrhage into a thyroid cyst. Another patient had a large diffuse goitre and hypothyroidism. There was no history of drug-ingestion, and tests to detect autoimmune thyroiditis, dyshormonogenesis, and iodine deficiency proved negative. Case 24 had a nodule $1 \frac{1}{4}$ by 2 in. ( 3 by $5 \mathrm{~cm}$.) in the left lobe of his thyroid when first seen. This disappeared completely during the next few months without treatment and he has remained clinically euthyroid. Radioiodine tests showed a "small-pool pattern" and there was no suppression of uptake after triiodothyronine administration (40 $\mu$ g. t.i.d. for nine days).

\begin{tabular}{|c|c|c|c|c|c|c|c|c|c|}
\hline \multirow{3}{*}{$\begin{array}{l}\text { Case } \\
\text { No. }\end{array}$} & \multicolumn{4}{|c|}{${ }^{131} \mathrm{I}$ Test } & \multirow{3}{*}{$\mid \begin{array}{c}\text { P.B. }{ }^{127} \mathrm{I} \\
(\mu \mathrm{g} . / \\
100 \mathrm{ml} .)\end{array}$} & \multirow{3}{*}{$\begin{array}{c}\text { Precip- } \\
\text { itin } \\
\text { Test }\end{array}$} & \multirow{3}{*}{ C.F.T. } & \multirow{3}{*}{$\begin{array}{c}\text { E.S.R. } \\
\text { (mm. } \\
1 \mathrm{st} \\
\mathrm{hr} .)\end{array}$} & \multirow{3}{*}{ Biopsy } \\
\hline & \multicolumn{2}{|c|}{$\begin{array}{l}\text { Neck Uptake } \\
\% \text { Dose }\end{array}$} & \multicolumn{2}{|c|}{$\begin{array}{l}\% \text { Dose } / 1 \text {. Plasma } \\
\text { at } 48 \text { Hours }\end{array}$} & & & & & \\
\hline & $4 \mathrm{hr}$. & $48 \mathrm{hr}$. & T.P.I. & P.B.I. & & & & & \\
\hline $\begin{array}{l}10 \\
11 \\
12\end{array}$ & $\begin{array}{l}37 \cdot 9 \\
17 \cdot 2\end{array}$ & $\begin{array}{l}64 \cdot 3 \\
19 \cdot 2\end{array}$ & $\begin{array}{l}0.52 \\
0.92\end{array}$ & $\begin{array}{l}0.43 \\
0.61\end{array}$ & $\begin{array}{l}4 \cdot 6 \\
1 \cdot 2 \\
4 \cdot 4\end{array}$ & \pm & $\begin{array}{l}++ \\
++\end{array}$ & $\begin{array}{l}20 \\
31\end{array}$ & + \\
\hline $\begin{array}{l}13 \\
14\end{array}$ & $\begin{array}{l}37 \cdot 1 \\
14 \cdot 1\end{array}$ & $\begin{array}{l}39 \cdot 2 \\
18 \cdot 1\end{array}$ & $\begin{array}{l}1.09 \\
0.24\end{array}$ & $\begin{array}{l}0.95 \\
0 \cdot 14\end{array}$ & $\begin{array}{l}1.5 \\
0.5\end{array}$ & + & ++ & $\begin{array}{l}46 \\
26\end{array}$ & + \\
\hline
\end{tabular}

T.P.I. $=$ Total plasma ${ }^{131}$ I. P.B.I. $=$ Protein-bound ${ }^{131}$ I. C.F.T. $=$ Complementfixation test.

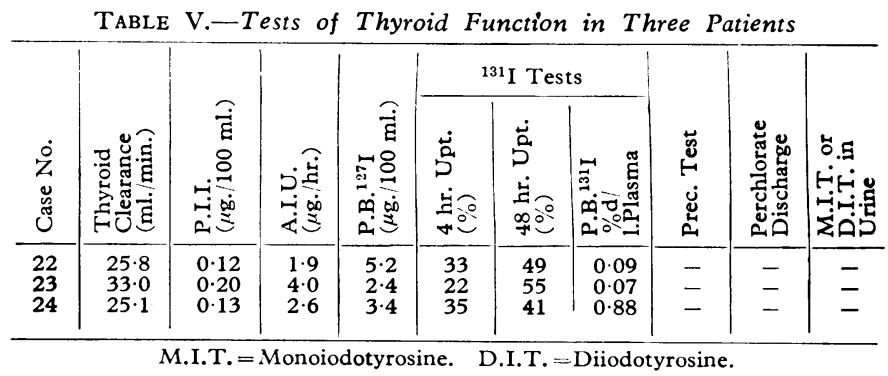

\section{Discussion}

It appears that, in males, non-toxic goitre is rarely " simple." In our group several types have been recognized, some of which are often thought to be rare. Five patients had biochemical evidence of iodine deficiency as shown by a plasma inorganic iodine of $0.07 \mu \mathrm{g} . / 100 \mathrm{ml}$. or less. In the West of Scotland, where goitre is relatively uncommon, severe degrees of iodine deficiency are rare except in the case of dietary eccentricity. The major part of our dietary intake of iodine is normally provided by sea-fish. Three of the five males in this group ate fish only rarely or not at all. It is not known why iodinedeficiency goitre is relatively common in females but apparently occurs in males only when the dietary intake of iodine is extremely low. It is of interest in this connexion that one patient had Klinefelter's syndrome, proved by XXY chromosomal pattern. Non-toxic goitre in Klinefelter's syndrome is well documented (Burt et al., 1954 ; Brit med. F., 1963 ; Fraser, 1963) and the incidence of goitre in this condition would appear to be higher than the incidence in normal males. It may be that possession of an extra $\mathrm{X}$ chromosome is associated with a greater tendency to goitre as is seen in females.

In all patients with goitre a history of drug-ingestion (iodinecontaining drugs and other goitrogens) should be sought. In the present series four patients had a drug-induced goitrethree due to iodine and one to carbimazole. We have previously presented evidence that the basic abnormality in some cases of iodine goitre is an inability of the thyroid to limit the uptake of iodine when large amounts are available to it (Harrison et al., 1963). Excessive amounts of iodine in the thyroid appear to 
inhibit the organic binding of iodine to tyrosine, as do antithyroid drugs such as carbimazole. Case 9 , with a carbimazole-induced goitre, is discussed further in the Appendix.

Five patients had autoimmune thyroiditis. This disease is said to occur only rarely in the male (Lindsay et al., 1952), but in our group it was an important cause of goitre.

The high incidence of thyroid tumours in the present series may partly be due to referral of patients to this clinic, which has facilities for radioiodine therapy.

In areas where goitre is relatively infrequent non-toxic goitre in the male is rarely "simple." In such patients further investigation to determine the aetiology of the goitre is essential. Autoimmune thyroiditis, neoplasm, and goitrogens were common causes in our series.

\section{Summary}

The causes of non-toxic goitre in 24 males have been studied; seven had thyroid tumours, five iodine-deficiency goitres, five autoimmune thyroiditis, four drug-induced goitres, and in three the aetiology was uncertain.

At least three of those with iodine-deficiency goitres had unusual dietary histories in that they never ate fish. In the absence of such a history another cause for the goitre is probable.

We are indebted to Professor E. J. Wayne for his encouragement and advice. This work has been supported by grants from the Secretary of State for Scotland on the recommendation of the Advisory Committee on Medical Research, and from the Medical Research Council.

\section{Appendix}

Case 9.- This man had taken $30 \mathrm{mg}$. of carbimazole daily for three years, after a diagnosis of thyrotoxicosis had been made at another hospital. His goitre had gradually increased in size and

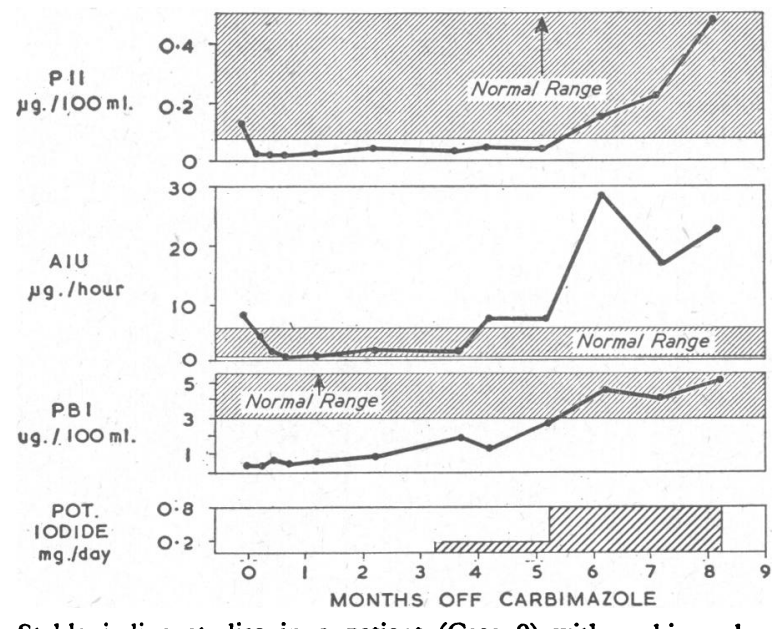

Stable iodine studies in a patient (Case 9) with carbimazoleinduced goitre. Shaded areas represent normal ranges. was approximately $200 \mathrm{~g}$. when he was first seen at our clinic. $\mathrm{He}$ was then clinically hypothyroid. The results of serial tests before and after withdrawal of carbimazole are shown in the Chart. Initially the thyroid clearance and absolute iodine uptake were high, probably due to the increased thyroidal iodine space produced by goitrogens (Halmi et al., 1959). The iodine utilization, however, was poor, as shown by the high absolute iodine uptake and the low serum protein-bound iodine. This is because much of the iodine taken up by the gland is not bound to tyrosine in such cases but discharged in inorganic form (Stanbury et al., 1955). After withdrawal of the carbimazole the plasma inorganic iodine and the absolute iodine uptake both fell to below normal. It is interesting that the plasma inorganic iodine remained low for five months after carbimazole had been stopped. The probable reason is the progressive depletion of the intrathyroidal organic iodine stores which occurs while the goitrogen is taken. During this time both dietary iodine and iodine from the deiodination of thyroxine are excreted in the urine. Discontinuance of the goitrogen allows repletion of the thyroid stores at the expense of the plasma inorganic iodine. The plasma inorganic iodine became very low, and insufficient amounts of hormone were made. Hypothyroidism and a low serum proteinbound iodine persisted until the plasma inorganic iodine was restored to normal levels with supplements of $0.8 \mathrm{mg}$. of potassium iodide a day, after $0.2 \mathrm{mg}$. a day had produced no effect.

Deficient hormone production associated with severe dietary deficiency has been described by Beckers (1962) in the Congo. Our patient appears to have had hypothyroidism resulting from a severe drug-induced iodine deficiency.

\section{REFERENCES}

Alexander, W. D., Koutras, D. A., Crooks, J., Buchanan, W. W MacDonald, E. M., Richmond, M. H., and 'Wayne, E. J. (1962). Quart. F. Med., 31, 281

Anderson, J. R., Goudie, R. B., and Gray, K. G. (1959). Scot. med. F., 4,64

Beckers, C. (1962). L'Hormonogenèse dans les goitres endémiques et sporadiques. Thesis, University of Louvain.

Brit. med. F., 1963, 1, 866.

Buchanan, W. W., Koutras, D. A., Alexander, W. D., Crooks, J. Richmond, M. H., MacDonald, E. M., and Wayne, E. J. (1961). clin. Endocr., 21, 806

Burt, A. S., Reiner, L., Cohen, R. B., and Sniffen, R. C. (1954). Ibid., 14, 719.

Crooks, J., Murray, I. P. C., and Wayne, E. J. (1959). Quart. F. Med., 28, 211.

Dimitriadou, A., Fraser, T. R., Slater, J. D. H., and Wagner, H. (1961). Advances in Thyroid Research, edited by R. V. Pitt-Rivers, p. 313 Pergamon Press, London.

Farrell, L. P., and Richmond, M. H. (1961). Clin. chim. Acta, 6, 620.

Fraser, G. R. (1963). Brit. med. F., 1, 1284.

Galton, V. A., and Pitt-Rivers, R."(1959). Biochem. 7., 72, 310

Halmi, N. S., Granner, D. K., Doughman, D. J., and Smith, B. D. (1959). Endocrinology, 65, 607

Harrison, M. T., Alexander, W. D., and Harden, R. McG. (1963) Lancet, 1, 1238.

Kilpatrick, R., Milne, J. S., Rushbrooke, M., Wilson, E. S. B., and Wilson, G. M. (1963). Brit. med. 7., 1, 29 .

Koutras, D. A., Alexander, W. D., Buchanan, W. W., Crooks, J., and Wayne, E. J. (1960). Lancet, 2, 784.

Lindsay, S., Dailey, M. E., Friedlander, J., Yee, G., and Soley, M. H. (1952). 7. clin. Endocr., 12, 1578

McGirr, E. M. (1960). In Clinical Endocrinology 1, edited by E. B. Astwood, p. 133. Grune and Stratton, New York and London.

Macgregor, A. G., and Wayne, E. J. (1958). In Modern Trends in Endocrinology, edited by $\mathrm{H}$. Gardiner-Hill, p. 34. Butterworth, London.

Pileggi, V. J., Lee, N. D., Golub, O. J., and Henry, R. J. (1961). 7. clin. Endocr., 21, 1272 .

Stanbury, J. B., Ohela, K., and Pitt-Rivers, R. (1955). Ibid., 15, 54.

Wayne, E. J., Koutras, D. A., and Alexander, W. D. (1964). Clinical Aspects of Iodine Metabolism, p. 160 . Blackwell, Oxford. 